\title{
Behavioural errors and stock market investment decisions: recent evidence from Pakistan
}

Behavioural errors and investment decisions

\section{Kashif Rashid, Yasir Bin Tariq and Mamoon Ur Rehman COMSATS University Islamabad, Abbottabad Campus, Abbottabad, Pakistan}

\begin{abstract}
Purpose - This study examines the role of behavioural factors, such as confidence, optimism, pessimism and rational expectation, in affecting investment decisions in the Pakistani stock market.

Design/methodology/approach - Using daily trading data of Karachi Stock Exchange-100 index from January 2012 to December 2015, different regression models, including descriptive statistics and stationarity tests, are performed.

Findings - Results indicate that stock market trading has suffered from pessimistic behaviour of investors. In the first model, the authors find a positive sign of confidence and negative sign of optimism with the trading volume. The second model shows a positive role of confidence and rational expectations in affecting the trading volume in daily, Monday and Friday samples. The results of the third model show a negative sign of both optimism and rational expectation with the trading volume. Furthermore, the next model shows a negative sign of confidence combined with pessimism while testing their relationship with the trading volume. Finally, results of the final model suggest that optimism negatively affects the trading volume, and on the other hand, pessimism has a positive impact on the trading volume.

Research limitations/implications - The method and empirical testing of behavioural biases and their relationship with economic variable used in this study seem to be a promising way to better understand the role of psychology in deriving financial decisions for academics and policymakers.

Originality/value - This study uses secondary data for measuring behavioural biases and decomposes the effect between rational expectation and behavioural biases.
\end{abstract}

Keywords Behavioural biases, Behavioural finance, Confidence, Investments, Optimism, Pakistan,

Pessimism, PSX, Rational expectation, Stock market, Trading volume

Paper type Research paper

\section{Introduction}

Extensive research has confirmed the existence of anomalies and seasonality in assets' returns debate, both in developed and developing capital markets such as Friday and Monday effect (Keim and Stambaugh, 1984; Sias and Starks, 1995) and anomalies in small size capitalisation (Chen and Zhou, 2001). Similarly, anomalies are found in developing markets such as seasonality in Kuala Lumpur Stock Exchange (Pandey, 2002), anomalies and seasonality in Malaysia, Philippines, Singapore and Hong Kong (Aggarwal and Rivoli, 1989) and seasonal and cultural effect in various Asian countries (Chan et al., 1996).

The majority of behavioural finance studies are conducted in developed economies investigating a multitude of behavioural aspects (e.g. biases such as confidence, overconfidence, optimism, pessimism and herding) of individual investors and portfolio

(C) Kashif Rashid, Yasir Bin Tariq and Mamoon Ur Rehman. Published in Asian Journal of Accounting Research. Published by Emerald Publishing Limited. This article is published under the Creative Commons Attribution (CC BY 4.0) licence. Anyone may reproduce, distribute, translate and create derivative works of this article (for both commercial and non-commercial purposes), subject to full attribution to the original publication and authors. The full terms of this licence may be seen at http:// creativecommons.org/licences/by/4.0/legalcode

The authors are very grateful to the anonymous referees whose valuable comments have made it possible to improve this manuscript.
Received 10 September 2020 Revised 17 December 2020 20 February 2021

11 March 2021

1 April 2021

25 April 2021

7 June 2021

Accepted 20 June 2021

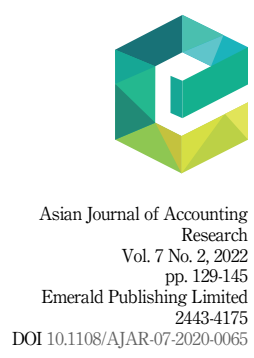


AJAR

7,2

130

managers concerning different market parameters (Gervais and Odean, 2015; Hoffmann et al., 2015; Hoffmann and Post, 2017; Kim and Nofsinger, 2007; Malmendier and Shanthikumar, 2007; Shanmugham and Ramya, 2012; Statman et al., 2006; Strydom et al., 2019). Cuthbertson et al. (2016) and Ahmad et al. (2017) reviewed the literature from an institutional investors' perspective and mainly covered studies from developed markets.

Traditional finance assumes that investors have complete knowledge of the market, urging for utility maximisation, rational decision-making and are risk-averse. On the macro-level, traditional finance is based on modern portfolio theory (Markowitz, 1952) and the efficient market hypothesis (EMH) (Malkiel and Fama, 1970). An efficient portfolio is based on risk and return criteria and investors' trade-off between risk and return to make investment decisions (Sharpe, 1964). The EMH states that all types of information are available to investors and reflected in the prices of securities. Proponents of the EMH argued that traders or fund managers could not beat the market and earn a risk-adjusted abnormal profit.

Behavioural finance assumes that information can affect investors' decisions, but information affects emotions and, in turn, leads to cognitive biases. Behavioural finance endeavours to explain the behaviour of individual investors and markets that deviate from the EMH (Kim and Nofsinger, 2007; Nofsinger, 2017).

Behavioural finance further assumes that human beings suffer from bounded rationality and have limited capacity to process information instead of utilising complete information for decision-making as assumed in traditional finance. Investors' irrational decisions are mainly because of human emotions and feelings (Tversky and Kahneman, 1992). Prospect theory provides a framework for decision-making based on gains and losses. Investors give more weightage to losses than gains of a similar amount. At the same time, traditional finance is based on the expected utility theory, which states that utility is the same and symmetrical for gains or losses. Thus, prospect theory has more explanatory power than utility theory in explaining investment decisions. Tversky and Kahneman (1992) posit that investment decisions are psychologically motivated rather than the computation of gains or losses. In short, behavioural finance is based on bounded rationality, prospect theory, cognitive limitations of information and satisficing instead of optimising and biases.

The national institutional environment defines the settings of the country's capital market. Pakistan is a common law country [1]. Its regulatory regime and corporate governance framework are mainly inspired by the UK and USA. Following the international trend of demutualisation of stock exchanges, the Pakistan Stock Exchange (PSX) was formed in January 2016 by merging the three regional stock exchanges, namely, Islamabad Stock Exchange, Lahore Stock Exchange and Karachi Stock Exchange. The PSX is considered one of the best performing emerging stock market (Mangi, 2016) but also suffers from high volatility episodes.

The behaviour of investors determines the nature and scope of activity on a stock market. Since a stock market is a significant source of equity capital for businesses, the stock market's performance is considered a yardstick of a country's economic strength and development (Rasheed et al., 2018). In emerging economies, Al-Tamimi (2006) investigated the investors' behaviour in the UAE, Chandra and Kumar (2012) examined heuristics in investment decisions in India and Feng and Seasholes (2005) examined Chinese firms and concluded that investors' experience reduces behavioural biases. There are also several studies from Pakistan investigating different behavioural dimensions of investors' decision-making (Moueed and Hunjra, 2020; Rasheed et al., 2018; Shah et al., 2018). These studies have used primary data to analyse behavioural biases and investigated different dimensions of behavioural errors than our study. 
Our study is an effort to intuitively use secondary data to analyse the impact of behavioural biases, i.e. confidence, pessimism, optimism and rational expectations, on trading volume (investment decisions).

\subsection{Significance of the study}

Shiller (1999) pointed out that to effectively understand financial markets' functioning, one must understand human participants' behaviour in it. With the growing interest in the emerging capital markets, it is pertinent to see whether various market anomalies are explained by human psychology in less developed and smaller-sized markets. This paper differs from previous studies on emerging markets in many ways. First, it uses secondary data for measuring behavioural biases. Although the primary data approach used by many studies offers some rich insights into the phenomena investigated, it is also embedded with respondent biases. In contrast, our study relied on stock market trading data, thus effectively capturing the actual outcome of irrational decision-making instead of what investors feel or perceive about their investment decision-making. Second, this paper decomposes the relationship between rational expectation and behavioural biases. Furthermore, this paper contributes to increase the awareness of investors, stockbrokers and fund managers that information is not the sole reason for informational efficiency. Information influences behaviour, and consequently, behaviour influences investment decisions. Finally, this study offers updated contextual evidence on this topic from Pakistan.

\section{Literature review}

While traditional finance theories (e.g. Portfolio, EMH) try to argue and explain why financial markets are efficient, behavioural finance theories attempt to explain the reasons behind the evidence of market inefficiency and anomalies. Therefore, in a way, behavioural finance explains how and why markets are inefficient (Asad et al., 2018). Shiller (2003) suggested that volatility caused by humans' irrational behaviour is an intrinsic characteristic of all capital assets markets. Shiller, the 2013 Noble laureate, was among the few who provided early warning of tech and housing bubbles, an indication that markets and their participants are not rational. In the rest of this section, we have briefly discussed relevant empirical literature.

Tuyon and Ahmad (2016) argued that adoptive rationality in the Malaysian Stock Market determines the prices and makes the market stable leading to the adopted and bounded market efficiency. Filip et al. (2015) documented herding behaviour among investors in Vienna and Prague capital markets. Vieira and Pereira (2015) analysed the investors' behaviour in the Portuguese financial market. They found that herding intensity is negative and statistically significant, which provides evidence that investors imitate each other in an organised way rather than using private information and acting irrationally.

Toma (2015) investigated the behavioural factors regarding investment in Bucharest's Romanian Stock Market. Investors in this market showed overconfidence, herding behaviour, disposition effect and factor of representativeness bias. Investors' age and frequent trading mostly influenced the returns and profitability in the market. Dhaoui and Khraief (2014) reported that investors' beliefs influence market trends and trading intensity in the French market.

In a study of two emerging economies, i.e. Romania and Brazil, Oprean and Tanasescu (2014) found that behavioural errors such as anxiety, pessimism, optimism and depression have a strong influence on investment decision-making compared to rational investment behaviour.

\section{Behavioural errors and investment decisions}


AJAR

7,2

132

Oprean (2014) tested the role of behavioural factors in affecting the humans' financial decisions in Brazil and Romania and found that trading is affected by the investors' irrational decisions. Furthermore, Trifan (2020) tested the role of various behavioural biases and stock market returns in Romania, Poland, Hungary, Slovenia, the Slovak Republic and the Czech Republic and found that judgement and emotions have a significant bearing on the stock market. The results suggested that investors in Poland are pessimistic, while in Romania, Hungary and the Czech Republic, optimism influences the trading activity.

The relationship between investor biases and markets' trading behaviour has been studied by Angelini and Cavapozzi (2017), Marquardt et al. (2019). Rocciolo et al. (2019) connected optimism to investors' expectations concerning the market's risk, political and financial occasions.

Volatility in the global financial market is explained by overconfidence bias, as evident from the study conducted by Jlassi et al. (2014). Their study confirmed the phenomena by providing empirical evidence that overconfidence exists in advanced Latin American, Asian, European and Mideast African markets except for Chile.

Investors' demographic factors, such as education, age, occupation and income, have a strong influence on investment avenue preferences.

\subsection{Confidence}

Behavioural scientists defined confidence as a feeling or state of mind in which one believes in his/her abilities. Furthermore, overconfidence is when someone overestimates his/her abilities (Daniel and Titman, 1999; Ricciardi and Simon, 2000). Overconfidence influences trading activities and affects investment growth (Bakar and Yi, 2016; Tuyon and Ahmad, 2016). Overconfidence affects the decision-making process as managers overestimate their ability to predict future benefits (Ben-David et al., 2007). Bakar and Yi (2016) reported a significant relationship between overconfidence and the investor's decision-making.

Past performance and achievement enhance confidence, and this mechanism was confirmed by Gervais and Odean (2015). They examined equity traders' behaviour and concluded that high market return enhances investors' confidence, although returns are market-wide. Parveen and Siddiqui (2018) and Shah et al. (2018) reported a negative relationship between overconfidence and investment decisions. Overconfidence is one of the determinants of market volatility and causes market disturbance (Jlassi et al., 2014). Boussaidi (2013) found a unidirectional causality between trading volume and return volatility, supporting the market's overconfidence phenomena. Furthermore, Javed et al. (2017) also confirmed that overconfidence positively impacts perceived investment performance. Hayat and Anwar (2016) pointed out that financially literate investors are most likely to be overconfident.

Overconfident investors rely upon the accuracy of the private information compared to the reliability of publicly available information and hence overestimate the precision of their private information. This overconfidence induces trading but reduces investment performance (Oberlechner and Osler, 2008; Odean, 1998). On the other hand, some researchers have opposite views and argue that overconfident investors earn higher returns (Anderson et al., 2005). Overconfident investors only consider recently occurred events (recency problem) while forgetting about trivial probable risks. This leads to a higher level of potential losses disturbing investors' confidence level and their risk tolerance level (Bracha and Brown, 2012; Van den Steen, 2004).

Optimistic and pessimistic investors influence capital markets. Optimistic investors are risk-takers and recklessly invest, which consequently raises security prices, while pessimistic investors being risk-averse are reluctant to invest, which leads to lower security prices. Optimistic investors are hopeful about happening in the future and hence make irrational transactions, which induces trading volume (Oprean and Tanasescu, 2014). 
From the literature review on overconfidence presented above, it is evident that decisionmaking biases can impact the investor's risk perception, investment performance and trading volume.

\subsection{Optimism and pessimism}

All the behavioural errors, mainly pessimism, optimism, anxiety and depression are against rational behaviour. Anomalies exist in the stock markets, and few investors earn abnormal profits due to their irrational behaviour. In stock markets, some humans show animal instinct and herding behaviour (crowd behaviour) to feel safe in the market (Oprean and Tanasescu, 2014). Information as good or bad news influences investors' behaviour, making them optimistic or pessimistic. This behaviour (optimism or pessimism) sometimes determines future trading and volatility in the stock market.

Optimistic bias tends to overestimate the favourable outcomes based on investors' expectations (Astebro et al., 2007). Boussaidi (2013) provided weak evidence that investors overreact on the earning information. The French stock market portrays a behavioural trend in investment decision-making where pessimism is dominant over-optimism. This is because optimism takes a while for its reinforcement, but to be the pessimist, even a small shock is enough. This suggests that investors' feelings and beliefs influence their investment decision- making (Dhaoui and Khraief, 2014). Bashir et al., (2019) reported an insignificant relationship between optimism and investor decision-making.

The mood of the investor affects investment decisions. A positive (negative) mood leads to optimistic (pessimistic) decisions (Kaplanski et al., 2015). Optimistic investors expect a higher level of financial returns from their investments (Aspara, 2013). Optimism bias has a significant bearing on the risk-taking behaviour of the investors who are willing to take an elevated level of risk (Menon et al., 2009) and influence stock returns (Dimmock and Kouwenberg, 2010). Finally, the research also shows an existing link between optimism and investment decision- making (Astebro et al., 2007; Barber and Odean, 2008; Krizan and Windschitl, 2007; Puri and Robinson, 2007).

\subsection{Rational expectation}

Muth (1961) introduced the rational expectation hypothesis, which was further developed by Lucas and Prescott (1971). This hypothesis posits that agents do not commit a systematic error in forecasting, yet they consider all the available information. However, the basis for Muth's work was found in the early research of Galton (1907), who argued that a single expectation is wrong. However, an aggregation of every single prediction can provide fair expectations in the market.

Recent empirical and experimental studies do not support this approach and reveal that agents are incapable of making a rational prediction (Branch, 2004; Evans et al., 2001; Sargent, 1993). The agents make an adaptive rule for prediction, which is based on past expectation and past realisation. In a recent experimental study by Colasante et al. (2017), it was found that aggregate forecasts compared to individual ones do not provide unbiased expectations. Differences exist amongst researchers to explain rational expectation theory in investment decisions. Our study examines whether past expectation and past realisation can or cannot predict stocks' future prices.

In an efficient market, all available information is embedded in asset prices. Consequently, investors use equilibrium prices as a strong base to make their expectations as and when new information hits the market. Nevertheless, Hassan and Mertens (2017) reported contradictory results that there is less propensity for investors to make correlated errors because, in the economy, households are not entirely rational.
Behavioural
errors and
investment
decisions

133 
AJAR

7,2

134

Kodres and Pritsker (2002), by using a rational expectation model, interestingly found that contagion even occurs in countries where asset prices are not affected by common macroeconomic factors. The possible reason for contagion is that investors revise and rebalance their portfolios according to their expectations. Countries with less efficient markets and having asymmetric information are exposed to contagion from other countries. So, investors form their predictions based on past expectations and past performances.

This study tests the role of behavioural biases in affecting trading behaviours in Pakistan. The Pakistani capital market follows the characteristics of the developing markets, which include weak judicial and regulatory authority, poor form of transparency, weak flow of the financial information, lack of proper market for corporate control, political instability, corruption, nepotism, high inflation, concentrated shareholdings and an illiquid market (Rashid and Islam, 2013). These are the unique conditions/environment where the role of behavioural biases will be tested. This paper models rationalism in investment decisions based on rational expectation theory and the theory of price movement. In this theory, the expected return is a function of the previous day's return and the error term.

\section{Methodology}

This section includes data, variables and their measurement used in the study. The details are as follows.

\subsection{Data and variables}

Four years of daily trading data (January 2012 to December 2015) of the Karachi Stock Exchange (KSE)-100 index were obtained from PSX's website. The PSX was established in January 2016 by merging the country's three stock exchanges, i.e. Islamabad, Lahore and Karachi Stock Exchanges. Due to this structural transformation, the study used the data till December 2015. Also, since the incorporation of PSX, the overall trading volatility has increased. In retrospect, the 2012-2015 period followed a steady growth in the stock market. During these four years, there were no market abnormalities due to political or other global reasons. A study period without any market abnormality offers an excellent opportunity to assess investors' actual behaviour under normal circumstances, which is not possible otherwise. The 2016-2020 period includes the two major and one smaller level market crash. Finally, the average annual volume of shares traded during these years, i.e. 2016-2019 [2], is less than the paper's study period (2012-2015), which indicates that due to increased volatility, investors were trading reluctantly.

This paper elaborates on the impact of behavioural biases such as confidence, optimism and pessimism on investing decisions. Table 1 explains the variable used in this study.

$\{$ Click here to see Table 1$\}$

\subsection{Research methods}

This study has used descriptive statistics to explain the data, augmented Dicky-Fuller test for checking stationarity and OLS regression to test the hypothesis.

\subsection{Measurement of variables}

Behavioural biases are modelled based on the literature which provided operational definitions (Oprean and Tanasescu, 2014; Ricciardi and Simon, 2000). These are expressed as mathematical inequalities in this section.

3.3.1 Confidence. Previous day/week returns are used to measure investors' confidence to trade on the current day. If the return on previous day/week is non-negative (greater than or 
equal to zero), then the investor will gain enough confidence to trade, while in case the return on the previous day/week is negative, the investor would hesitate to trade.

Based on the above discussions, we suggest the below proposition expressed in mathematical inequalities for further empirical testing.

$$
\begin{gathered}
R_{t-1} \geq 0 \rightarrow \text { There will be trading } \\
R_{t-1}<0 \rightarrow \text { There will be no trading }
\end{gathered}
$$

where $R_{t-1}$ is the previous day return of KSE-100 index, i.e. a day before the trading volume. We will examine this in the regression analysis.

3.3.2 Optimism. Optimism refers to a feeling when an investor overestimates the probability of favourable outcomes and underestimates the likelihood of unfavourable outcomes. Optimistic investors set their profit level above their previously earned profit, and they forecast their future return based on the previous day's return. If the last day's returns are above plus one standard deviation, investors will be optimistic about future returns; hence, they will trade on this specific day (Oprean and Tanasescu, 2014). On the other hand, investors will avoid trading if their previous day's return is lower than one standard deviation from the mean.

Below mentioned propositions are made based on the above discussion, as shown in mathematical inequalities.

$$
\begin{gathered}
R_{t-1} \geq \bar{R}+\sigma \rightarrow \text { There will be trading } \\
R_{t-1}<\bar{R}+\sigma \rightarrow \text { There will be no trading }
\end{gathered}
$$

where $R_{t-1}$ is the previous day return, $\bar{R}$ is the average return for the whole period under analysis and $\sigma$ is the standard deviation of the return.

3.3.3 Pessimism. In this study, pessimism is measured through previous day losses. If the previous days' return is below this threshold, the investor will not trade. On the other hand, if the return breaks this minimum threshold, investors tend to trade (Oprean and Tanasescu, 2014).

If previous days' return is greater or equal to the difference of mean and standard deviation, then investors will tend to trade; otherwise, they will refrain from trading activities.

Above mentioned discussion is concluded in the below propositions as expressed in mathematical inequalities:

$$
\begin{gathered}
R_{t-1} \geq \bar{R}-\sigma \rightarrow \text { There will be trading } \\
R_{t-1}<\bar{R}-\sigma \rightarrow \text { There will be no trading }
\end{gathered}
$$

where $R_{t-1}$ is the previous day return, $\bar{R}$ is the average return for the whole period under analysis and $\sigma$ is the standard deviation of the return.

3.3.4 Rational behaviour. Market equilibrium prices are used as bases for future expectations, and when new information hits the market, it disturbs the equilibrium. In an efficient market, asset prices reflect all the available information, but it takes time to absorb new information. Any new information that affects prices also tends to affect investors' expectations, which they make from equilibrium prices. It infers that investors sometimes make related errors.

Mathematically, it is expressed as below:

$$
E(R)=R_{t-1}+\varepsilon_{t-1}
$$

where $E(R)$ is expected return, $R_{t-1}$ is previous day returns and $\varepsilon_{t-1}$ is the error term of the equation. 
AJAR

7,2

In the equation, the expected return on investment is equal to the previous day return of that investment plus the error term. The error term represents the new information, which is unknown to investors trading in the stock market.

3.3.5 Investment decision. The dependent variable in this study is investment decisionmaking. KSE-100 index's trading volume is used to operationalise this variable.

\subsection{Regression model}

Trading volume is the dependent variable in the regression model, and confidence, optimism, pessimism and rational expectations are the independent variables. There are three samples used in this study. These include daily behaviour, Monday behaviour and Friday behaviour sample. In these regressions, we have examined the impact of each of the behavioural errors and rational expectations on the investment decisions (trading volume of KSE 100 index).

Traditionally, we would model the regression equation as

$$
\ln _{\text {(Volume })}=\beta_{0}+\beta_{1} \text { Confidence }+\beta_{2} \text { Optimism }+\beta_{3} \text { Pessimism }+\beta_{4} \text { Rational }+€
$$

However, it will not be prudent to use the above-mentioned regression model because the investor may feel confident and optimistic at the same time but not pessimistic and rational. Instead, the following regression specifications are used.

When an investor may be confident and optimistic at the same time but not pessimistic and rational, then

$$
\ln _{\text {(Volume })}=\beta_{0}+\beta_{1} \text { Confidence }+\beta_{2} \text { Optimism }+€
$$

When an investor is confident and rational at the same time but neither optimistic nor pessimistic, then

$$
\ln _{(\text {Volume })}=\beta_{0}+\beta_{1} \text { Confidence }+\beta_{2} \text { Rational }+€
$$

When an investor is optimistic and rational at the same time but neither confident nor pessimistic, then

$$
\ln _{(\text {Volume })}=\beta_{0}+\beta_{1} \text { Optimism }+\beta_{2} \text { Rational }+€
$$

When an investor is confident and pessimistic at the same time but not optimistic and rational, then

$$
\ln _{\text {(Volume })}=\beta_{0}+\beta_{1} \text { Confidence }+\beta_{2} \text { Pessimism }+€
$$

When an investor is optimistic and pessimistic at the same time but not confident and rational, then

$$
\ln _{(\text {Volume })}=\beta_{0}+\beta_{1} \text { Optimism }+\beta_{2} \text { Pessimism }+€
$$

All the above-mentioned five regression models (Equation 9-13) were estimated individually using ARMA maximum likelihood method to test the desired mechanism in the market.

\section{Results and analysis}

This section contains results of descriptive statistics, augmented Dicky-Fuller test for stationarity and OLS regression.

Table 2 reports descriptive statistics for daily trading data. The average trading volume is 8.076. This indicates a lack of confidence in short-range trading even if optimistic investors could escalate trading volume. It is also evident from the low standard deviation (0.218) of trading volume that trading volume does not manifest confident investors' aggressive 
behaviour. The average confidence is 0.001 with the range and standard deviation of 0.089 and 0.008 , respectively, indicating that investors prevail in extreme pools, i.e. confident and pessimist. Investors are less optimistic $(-0.008)$ and more pessimistic $(0.008)$. The range of 0.089 divulges that investors vary from optimistic to pessimistic.

The mean value for rational expectation is lowest among other variables, which augmented the claim that investors suffer from behavioural biases, such as pessimism and irrational behaviour. Oprean and Tanasescu (2014) reported similar findings that investors' irrational behaviour induces trading on the stock exchange in emerging markets.

Pakistani capital market consists of investors depicting diverse behaviours. The mean value of pessimism is higher than confidence, which confirms that pessimistic investors dominate the market.

\{Click here to see Table 2 \}

This pessimism is mainly due to political instability and large-scale natural disasters in Pakistan. Another apparent reason is terrorism, which is one of the main problems affecting Pakistani society.

Augmented Dickey-Fuller test is applied to check the stationarity of all the variables. Test results indicated that time series data are stationary in all the three data samples except for rational expectation in the Monday sample.

\subsection{Regression analysis}

Separate results for each estimated regression model are tabulated and interpreted. $R$-squared value shows that $58.5 \%$ change in the investment decision is explained by confidence and optimism (the model's explanatory variables).

The proposition that a positive return on the previous day $\left(R_{t-1} \geq 0\right)$ can induce the trading volume of the current day can explain the association of investors' confidence with investment decisions. Past returns on market securities change the level of investors' confidence. The results in Table 3 imply that positive returns boost up investor confidence to invest in the stock market, which consequently increases trading volume. Gervais and Odean (2015) documented a similar result that a trader judges his skills from success and failure, and success makes him overconfident.

The model shows that trading volume is positively related to the lagged positive returns of a day, which further confirmed our claim that past success increases investors' confidence level. This motivates them to trade and invest in the stock market.

Trading volume is less sensitive to investors' confidence on Friday than in the daily data sample, which shows that other factors affect variation in trading activities, such as the Friday effect. Results of this study are consistent with Jlassi et al. (2014), Boussaidi (2013), Oberlechner and Osler (2008), Bakar and Yi (2016) and Javed et al. (2017).

\begin{tabular}{|c|c|c|c|c|c|c|}
\hline Variables & Daily & Friday & Daily & Monday & Friday & \\
\hline Confidence & 833.289 & 306.765 & 7229.024 & 1446.444 & 1361.116 & \\
\hline Probability & $(0.000)$ & $(0.000)$ & $(0.000)$ & $(0.000)$ & $(0.000)$ & \\
\hline Optimism & -831.114 & -306.461 & & & & \\
\hline Probability & $(0.000)$ & $(0.000)$ & & & & Table 3. \\
\hline Rational expectations & & & 7226.849 & 1445.333 & 1360.811 & Regression results of \\
\hline Probability & & & $(0.000)$ & $(0.000)$ & $(0.000)$ & $\begin{array}{l}\text { confidence and } \\
\text { cons }\end{array}$ \\
\hline$R$-squared & 0.587 & 0.266 & 0.587 & 0.259 & 0.266 & optimism on \\
\hline Adj. $R$-squared & 0.585 & 0.250 & 0.585 & 0.244 & 0.250 & investment decision, \\
\hline Durbin-Watson statistics & 1.904 & 1.997 & 1.90 & 2.00 & 1.99 & confidence and rational \\
\hline$N$ & 990 & 188 & 990 & 203 & 188 & expectations \\
\hline
\end{tabular}

Behavioural errors and investment decisions 
AJAR

7,2

\section{8}

The second proposition explained the negative relationship of optimism with trading volume. This proposition assumes that the previous day's returns are more than the summation of mean returns and standard deviation $\left(R_{t-1} \geq \bar{R}-\sigma\right)$. Optimism bias tends to overestimate the probability of positive events and underestimate the likelihood of adverse events (Shepperd et al., 2002).

Our results confirmed that optimism bias had reduced trading volume in the Pakistani stock market, as evident from Table 3 , which shows a negative relationship of trading volume with the lag of previous day returns, which are greater than the mean and standard deviation.

The results are inconsistent with the previous literature. The possible reason for the inconsistency is that different method of measurement of variables provides different results. Measurement for optimism (overestimation) in this study is abnormal returns, more than mean and standard deviation $\left(R_{t-1} \geq \bar{R}+\sigma\right)$. This makes investors to start believing that the stock market is moving towards a bubble. Hence in this situation, they tend to sell their stock.

Table 3 summarises equation (10) that shows the relationship of confidence and rational expectation with trading activities. Confidence has a tangible impact on trading activities in the Pakistani capital market. The fourth proposition stated that investors tend to transact on the day when the expected return $\left(E(R)=R_{t-1}+e_{t-1}\right)$ becomes equal to the sum of the previous day's returns and the error term. Investors' expectation regarding future return is based on the error term $\left(e_{t-1}\right)$ of the previous day that positively affects trading activities for daily, Monday and the Friday sample. The error term $\left(e_{t-1}\right)$ captures the effect of other information that influences investors' decision-making process.

Furthermore, rational expectations also vary with public announcements, which affects trading volume accordingly. Our results are consistent with the findings of Kim and Verrecchia (1991), suggesting that the traders achieve optimal portfolios before public announcements and new announcements change the trader's mind to enter in a new round of trading. Table 3 shows that trading volume is positively influenced by rational expectations confirming that new public announcements are interpreted positively by investors in making investment decisions.

Table 4 shows that optimism and rational expectation negatively affect investment decisions for the samples of daily and Friday trading. The results are statistically significant at a $5 \%$ confidence level.

Optimism negatively impacts trading volume as depicted in the first regression model, while rational expectation negatively affects trading when combined with optimism. Optimism suppresses the effects of rational expectations. New public announcements and information change optimistic investors' minds to reduce transactions and counter artificial trading. The same announcements are interpreted differently by optimistic and pessimistic investors.

The adjusted $R$-squared value showed that in the daily trading sample, the explanatory variables explain $58 \%$ of the variation in the dependent variable. Similarly, $25 \%$ of the

Table 4.

Regression results of optimism and rational expectations

\begin{tabular}{lcc}
\hline Variables & Daily & Friday \\
\hline Optimism & -939.398 & -395.627 \\
Probability & $(0.000)$ & $(0.000)$ \\
Rational expectations & -941.573 & -395.9317 \\
Probability & $(0.000)$ & $(0.000)$ \\
$R$-squared & 0.587 & 0.266 \\
Adj. $R$-squared & 0.585 & 0.250 \\
Durbin-Watson statistics & 1.90 & 1.99 \\
$N$ & 990 & 188 \\
\hline
\end{tabular}


variation is explained in the case of Friday trading. A lower level of autocorrelation exists, as revealed by Durbin-Watson values for all the samples.

Table 5 portrays the results of equation (12), which show the relationship of confidence and pessimism with trading volume. It shows that confidence negatively impacts investment decisions for all the three samples, and results are statistically significant. On the other hand, pessimism affects investment decisions positively, and results are statistically significant at a $5 \%$ confidence level for all three samples.

The third proposition suggests that when the previous day's returns $\left(R_{t-1} \geq \bar{R}-\sigma\right)$ are more than a difference of mean return and standard deviation, this will induce trading. Investors are preemptive in mitigating the impact of information, which increases the tendency to expect negative returns. At the same time, confidence has a negative effect on trading volume when combined with pessimism in the multiple regression model.

Table 5 summarises the results of the regression model expressed in equation (13) to analyse the impact of optimism and pessimism on trading volume. It shows that optimism negatively affects investment decisions in all three samples, while pessimism positively affects investment decisions. These results are statistically significant at $5 \%$ level.

In the last regression model, trading volume is positively related with the lagged returns of the day, which are more than the difference of mean return and standard deviation $\left(R_{t-1} \geq \bar{R}-\sigma\right)$ and negatively associated with the lagged returns when these returns are more than the sum of mean returns and standard deviation $\left(R_{t-1} \geq \bar{R}-\sigma\right)$. Optimism is measured through the lagged values of abnormal returns, and few investors make an attempt to achieve it. The results imply that after achieving the abnormal positive returns, investors perceived a high level of risk and become reluctant to trade, which declines the trading volume. However, pessimism leads to more investment and increases trading volume. This implies that pessimism occurs after investors suffer abnormal negative returns $\left(R_{t-1} \geq \bar{R}-\sigma\right)$ and tend to stop trading.

In contrast, pessimism ceases to exist when lagged returns break the threshold of negative abnormal returns that motivate investors to trade. Galanidis (2016) reported for Italy and Ireland that pessimism induces fluctuations in the trading volume. Similar findings were reported by Oprean (2014) for Romanian capital markets.

The results are also explained by considering the additional imperfections prevailing in the Pakistani capital markets. The first result presented in Table 3 shows that the mechanism suggesting a positive role of confident investors in affecting the trading volume remains unaffected by the financial, social and political problems. The result implies that confident investors make robust decisions improving the trading volume in the stock market. In contrast, optimism in the stock market deteriorates the trading volume level, implying that

\begin{tabular}{|c|c|c|c|c|c|c|}
\hline Variables & Daily & Monday & Friday & Daily & Friday & \\
\hline Confidence & -1077.205 & -10.219 & -557.313 & & & \\
\hline Probability & $(0.000)$ & $(0.000)$ & $(0.000)$ & & & \\
\hline Optimism & & & & -468.612 & -197.661 & \\
\hline Probability & & & & $(0.000)$ & $(0.000)$ & \\
\hline Pessimism & 1079.380 & 11.559 & 557.618 & 470.786 & 197.965 & \\
\hline Probability & $(0.000)$ & $(0.000)$ & $(0.000)$ & $(0.000)$ & $(0.000)$ & Table 5. \\
\hline$R$-squared & 0.587 & 0.240 & 0.266 & 0.587 & 0.266 & Regression results of \\
\hline Adj. $R$-squared & 0.585 & 0.225 & 0.250 & 0.585 & 0.250 & confidence and \\
\hline Durbin-Watson statistics & 1.904 & 1.977 & 1.99 & 1.904 & 1.99 & pessimism, optimism \\
\hline$N$ & 990 & 203 & 188 & 990 & 188 & and pessimism \\
\hline
\end{tabular}

Behavioural errors and investment decisions

139 
AJAR

7,2

140

additional issues in the Pakistani market dominate the investors' optimistic behaviour and reduce the trading volume.

The result of the following model (Table 3) shows a positive relationship of investors' confidence with the trading volume proving that additional imperfections are limited in affecting the investor's confidence. The result of the next variable shows that investors having rational expectations make correct decisions and improve the level of trading volume depicting that the problematic environment of the Pakistani market is limited in affecting this mechanism.

The relationship between optimistic investors in improving the level of trading volume (presented in Table 4) is dominated by the additional issues which distort the genuine mechanism leading to the diminished level of the trading volume. The relationship between rational expectations in affecting the trading volume is adversely affected by the social, political and financial issues prevalent in Pakistan. Due to these problems, investors having rational expectations do not improve the level of trading volume in Pakistan. The next result (Table 5) shows that the developing market's additional problems dominate the confident investors and trading volume relationship. This leads to a reduced level of trading volume despite the presence of confident investors in the Pakistani market.

The results of the final model shown in Table 5 suggest that imperfections in the Pakistani market dominate the optimistic investor's relationship with the trading volume, where optimistic phenomena prevalent in the developing market result in the deterioration of the level of the trading volume. The last result is a surprise where pessimism in the presence of social, political and financial problems leads to improved trading volume in the Pakistani stock market. These results are valuable in understanding the role of behavioural biases in making investment decisions in Pakistan.

\section{Conclusion}

This study has examined the effects of behavioural biases on investment decision-making prevailing in the Karachi Stock Exchange (now PSX) over four years, starting from 2012 to 2015. The study used OLS regression analyses to test the impact of investor's behaviour (biases) on investment decisions (trading volume).

Descriptive statistics showed that the Pakistani stock market is dominated by irrational behaviour. Furthermore, the trading volume is induced by pessimism and confidence. Overall, the stock market trading has suffered from the pessimistic behaviour of investors. The results after testing the combination of instruments relevant to the study are presented as follows.

The first combination of confidence and optimism provides us with a positive sign of confidence and optimism while testing their relationship with the trading volume. The second combination shows both the positive roles of confidence and rational expectations in affecting the trading volume in daily, Monday and Friday samples. This reveals that investors with stable behaviours fully interpret the information and make correct investment decisions. Finally, trading activities are positively affected by overconfidence, which is consistent with the prospect theory.

The results for the third model show a negative sign of both optimism and rational expectation. This indicates that pessimistic investors have irrational expectations, and investors having unreasonable expectations are pessimistic. The next model shows a negative sign of confidence when combined with pessimism while testing their relationship with the trading volume. The result indicates that higher confidence leads to optimism, and similarly, optimism leads to a higher level of investors' confidence in the market. The results of the final model suggest that optimism negatively affects the trading volume. On the other hand, pessimism has a positive impact on trading volume. Optimism bias and cognitive dissonance also encourage many individual investors to overestimate their investment results. 
The results showed that investors' confidence, optimism and rational expectations positively affect trading volume in KSE (now PSX). The regulatory authorities may take confidence-building measures for investors in the financial markets. These may include running investors' awareness seminars and vigilant acts by the stock exchanges in implementing the regulatory decisions taken by the Securities and Exchange Commission of Pakistan. Besides, constructing a proper policy framework will also enhance the confidence level of investors and will make them expect rationally by being optimistic and confident.

The study provides valuable insights into the irrational behaviour of Pakistani investors. It is worth mentioning that trading activities in stock exchanges mostly remain an anomaly. Further investigations can be made using alternative proxies of optimism and pessimism and their role in affecting trading volume in the stock market.

\section{Notes}

1. As a former British colony, Pakistan follows a common law system, along with the provisions of Islamic (Shariah) Law.

2. Year (Average trading volume): 2012 (111,084,447), 2013 (143,846,409), 2014 (136,605,400), 2015 (141,913,464), 2016 (130,555,236), 2017 (102,454,157), 2018 (96,572,026), 2019 (107,258,552)

\section{References}

Aggarwal, R. and Rivoli, P. (1989), "Seasonal and day-of-the-week effects in four emerging stock markets", The Financial Review, Vol. 24 No. 4, pp. 541-550, doi: 10.1111/j.1540-6288.1989. tb00359.x.

Ahmad, Z., Ibrahim, H. and Tuyon, J. (2017), "Institutional investor behavioral biases: syntheses of theory and evidence", Management Research Review, Vol. 40 No. 5, pp. 578-603, doi: 10.1108/ MRR-04-2016-0091.

Al-Tamimi, H.A.H. (2006), "Factors influencing individual investor behaviour: an empirical study of the UAE”, The Business Review Journal, Vol. 5 No. 2, pp. 225-232.

Anderson, A., Henker, J. and Owen, S. (2005), "Limit order trading behavior and individual investor performance", Journal of Behavioral Finance, Vol. 6 No. 2, pp. 71-89, doi: 10.1207/ s15427579jpfm0602_3.

Angelini, V. and Cavapozzi, D. (2017), "Dispositional optimism and stock investments", Journal of Economic Psychology, Vol. 59, pp. 113-128, doi: 10.1016/j.joep.2017.01.006.

Asad, H., Khan, A. and Faiz, R. (2018), "Behavioral biases across the stock market investors: evidence from Pakistan”, Pakistan Economic and Social Review, Vol. 56 No. 1, pp. 185-209, available at: http://pu.edu.pk/images/journal/pesr/PDF-FILES/8-v56_1_18.pdf.

Aspara, J. (2013), "The role of product and brand perceptions in stock investing: effects on investment considerations, optimism and confidence", Journal of Behavioral Finance, Vol. 14 No. 3, pp. 195-212, doi: 10.1080/15427560.2013.819803.

Åstebro, T., Jeffrey, S.A. and Adomdza, G.K. (2007), "Inventor perseverance after being told to quit: the role of cognitive biases", Journal of Behavioral Decision Making, Vol. 20 No. 3, pp. 253-272, doi: $10.1002 / \mathrm{bdm} .554$.

Bakar, S. and Yi, A.N.C. (2016), "The impact of psychological factors on investors' decision making in Malaysian stock market: a case of Klang valley and Pahang", Procedia Economics and Finance, Vol. 35, October 2015, pp. 319-328, doi: 10.1016/S2212-5671(16)00040-X.

Barber, B.M. and Odean, T. (2008), "All that glitters: the effect of attention and news on the buying behavior of individual and institutional investors", Review of Financial Studies, Vol. 21 No. 2, pp. 785-818, doi: 10.1093/rfs/hhm079. 
AJAR

7,2

Bashir, T., Mehmood, F. and Khan, A. (2019), "Comforting investments are rarely profitable: impediments in investor decision making”, Global Social Sciences Review, Vol. 4 No. 2, pp. 51-59, doi: 10.31703/gssr.2019(iv-ii).07.

Ben-David, I., Graham, J.R. and Harvey, C. (2007), "Managerial overconfidence and corporate policies”, NBER Working Paper No. 13711, available at: http:/www.nber.org/papers/w13711.pdf.

Boussaidi, R. (2013), "Representativeness heuristic, investor sentiment and overreaction to accounting earnings: the case of the Tunisian stock market”, Procedia - Social and Behavioral Sciences, Vol. 81 No. 1974, pp. 9-21, doi: 10.1016/j.sbspro.2013.06.380.

Bracha, A. and Brown, D.J. (2012), “Affective decision making: a theory of optimism bias”, Games and Economic Behavior, Vol. 75 No. 1, pp. 67-80, doi: 10.1016/j.geb.2011.11.004.

Branch, W.A. (2004), "The theory of rationally heterogeneous expectations: evidence from survey data on inflation expectations", The Economic Journal, Vol. 114 No. 497, pp. 592-621, doi: 10.1111/j. 1468-0297.2004.00233.x.

Chan, M.W.L., Khanthavit, A. and Thomas, H. (1996), "Seasonality and cultural influences on four Asian stock markets", Asia Pacific Journal of Management, Vol. 13 No. 2, pp. 1-24, doi: 10.1007/ BF01733814.

Chandra, A. and Kumar, R. (2012), "Factors influencing Indian individual investor behaviour: survey evidence", Decision, Vol. 39 No. 3, pp. 141-167, doi: 10.2139/ssrn.2029642.

Chen, C. and Zhou, Z.-G. (2001), "Portfolio returns, market volatility, and seasonality", Review of Quantitative Finance and Accounting, Vol. 17 No. 1, pp. 27-43, doi: 10.1023/A:1011253403965.

Colasante, A., Palestrini, A., Russo, A. and Gallegati, M. (2017), "Adaptive expectations versus rational expectations: evidence from the lab", International Journal of Forecasting, Vol. 33 No. 4, pp. 988-1006, doi: 10.1016/j.ijforecast.2017.06.003.

Cuthbertson, K., Nitzsche, D. and O'Sullivan, N. (2016), "A review of behavioural and management effects in mutual fund performance", International Review of Financial Analysis, Vol. 44, pp. 162-176, doi: 10.1016/j.irfa.2016.01.016.

Daniel, K. and Titman, S. (1999), "Market efficiency in an irrational world", Financial Analysts Journal, Vol. 55 No. 6, pp. 28-40, doi: 10.2469/faj.v55.n6.2312.

Dhaoui, A. and Khraief, N. (2014), "Sensitivity of trading intensity to optimistic and pessimistic beliefs: evidence from the French stock market", Arab Economic and Business Journal, Vol. 9 No. 2, pp. 115-132, doi: 10.1016/j.aebj.2014.05.008.

Dimmock, S.G. and Kouwenberg, R. (2010), "Loss-aversion and household portfolio choice”, Journal of Empirical Finance, Vol. 17 No. 3, pp. 441-459, doi: 10.1016/j.jempfin.2009.11.005.

Evans, G.W., Honkapohja, S. and Marimon, R. (2001), "Convergence in monetary inflation models with heterogeneous learning rules”, Macroeconomic Dynamics, Vol. 5 No. 1, pp. 1-31, doi: 10.1017/ S1365100501018016.

Feng, L. and Seasholes, M.S. (2005), "Do investor sophistication and trading experience eliminate behavioral biases in financial markets?", Review of Finance, Vol. 9 No. 3, pp. 305-351, available at: https://econpapers.repec.org/RePEc:oup:revfin:v:9:y:2005:i:3:p:305-351.

Filip, A., Pochea, M. and Pece, A. (2015), "The herding behaviour of investors in the CEE stocks markets", Procedia Economics and Finance, Vol. 32 No. 15, pp. 307-315, doi: 10.1016/S22125671(15)01397-0.

Galanidis, I. (2016), "The effect of behavioral finance on capital markets. The case of PIIGS (Portugal, Italy, Ireland, Greece, Spain)”, International Hellenic University, Greece, available at: https:// repository.ihu.edu.gr/xmlui/bitstream/handle/11544/15067/The-effect-of-Behavioral-Finance-onCapital-Markets.-The-case-of-PIIGS- \% 28Portugal-Italy-Ireland-Greece-Spain \% 29.pdf? sequence $=1$.

Galton, F. (1907), “Vox populi”, Nature, Vol. 75 No. 1949, pp. 450-451, doi: 10.1038/075450a0. 
Gervais, S. and Odean, T. (2015), "Learning to be overconfident", The Review of Financial Studies, Vol. 14 No. 1, pp. 1-27, doi: 10.1093/rfs/14.1.1.

Hassan, T.A. and Mertens, T.M. (2017), "The social cost of near-rational investment", American Economic Review, Vol. 107 No. 4, pp. 1059-1103, doi: 10.1257/aer.20110433.

Hayat, A. and Anwar, M. (2016), "Impact of behavioral biases on investment decision: moderating role of financial literacy", SSRN Electronic Journal. doi: 10.2139/ssrn.2842502.

Hoffmann, A.O.I. and Post, T. (2017), "How return and risk experiences shape investor beliefs and preferences", Accounting and Finance, Vol. 57 No. 3, pp. 759-788, doi: 10.1111/acfi.12169.

Hoffmann, A.O.I., Post, T. and Pennings, J.M.E. (2015), "How investor perceptions drive actual trading and risk-taking behavior", Journal of Behavioral Finance, Vol. 16 No. 1, pp. 94-103, doi: 10.1080/ 15427560.2015.1000332.

Javed, H., Bagh, T. and Razzaq, S. (2017), "Herding effects, over confidence, availability bias and representativeness as behavioral determinants of perceived investment performance: an empirical evidence from Pakistan stock exchange (PSX)", Journal of Global Economics, Vol. 6 No. 1, p. 13, doi: 10.4172/2375-4389.1000275.

Jlassi, M., Naoui, K. and Mansour, W. (2014), "Overconfidence behavior and dynamic market volatility: evidence from international data”, Procedia Economics and Finance, Vol. 13, December 2013, pp. 128-142, doi: 10.1016/S2212-5671(14)00435-3.

Kaplanski, G., Levy, H., Veld, C. and Veld-Merkoulova, Y. (2015), "Do happy people make optimistic investors?", Journal of Financial and Quantitative Analysis, Vol. 50 Nos 1-2, pp. 145-168, doi: 10. 1017/S0022109014000416.

Keim, D.B. and Stambaugh, R.F. (1984), "A further investigation of the weekend effect in stock returns", The Journal of Finance, Vol. 39 No. 3, pp. 819-835, doi: 10.1111/j.1540-6261.1984. tb03675.x.

Kim, K.A. and Nofsinger, J.R. (2007), "The behavior of Japanese individual investors during bull and bear markets", Journal of Behavioral Finance, Vol. 8 No. 3, pp. 138-153, doi: 10.1080/ 15427560701545598.

Kim, O. and Verrecchia, R.E. (1991), "Trading volume and price reactions to public announcements", Journal of Accounting Research, Vol. 29 No. 2, pp. 302-321, doi: 10.2307/2491051.

Kodres, L.E. and Pritsker, M. (2002), "A rational expectations model of financial contagion”, The Journal of Finance, Vol. 57 No. 2, pp. 769-799, doi: 10.1111/1540-6261.00441.

Krizan, Z. and Windschitl, P.D. (2007), "The influence of outcome desirability on optimism", Psychological Bulletin, Vol. 133 No. 1, pp. 95-121, doi: 10.1037/0033-2909.133.1.95.

Lucas, R.E. and Prescott, E.C. (1971), "Investment under uncertainty", Econometrica, Vol. 39 No. 5, pp. 659-681, doi: 10.2307/1909571.

Malkiel, B.G. and Fama, E.F. (1970), "Efficient capital markets: a review of theory and empirical work", The Journal of Finance, Vol. 25 No. 2, pp. 383-417, doi: 10.1111/j.1540-6261.1970. tb00518.x.

Malmendier, U. and Shanthikumar, D. (2007), “Are small investors naive about incentives?”, Journal of Financial Economics, Vol. 85 No. 2, pp. 457-489, doi: 10.1016/j.jfineco.2007.02.001.

Mangi, F. (2016), Pakistan Stocks Jump Most in a Year as MSCI Seen Luring Cash, Bloomberg, available at: https://www.bloomberg.com/news/articles/2016-06-15/pakistani-stocks-jump-mostthis-year-after-upgrade-from-msci.

Markowitz, H. (1952), "Portfolio selection”, The Journal of Finance, Vol. 7 No. 1, pp. 77-91, doi: 10.2307/ 2975974.

Marquardt, P., Noussair, C.N. and Weber, M. (2019), "Rational expectations in an experimental asset market with shocks to market trends", European Economic Review, Vol. 114, May 2019, pp. 116-140, doi: 10.1016/j.euroecorev.2019.01.009.
Behavioural errors and investment decisions 
AJAR

7,2

144

Menon, G., Kyung, E.J. and Agrawal, N. (2009), "Biases in social comparisons: optimism or pessimism?”, Organizational Behavior and Human Decision Processes, Vol. 108 No. 1, pp. 39-52, doi: 10.1016/j. obhdp.2008.05.001.

Moueed, A. and Hunjra, A.I. (2020), "Use anger to guide your stock market decision-making: results from Pakistan", Cogent Economics and Finance, Vol. 8 No. 1, doi: 10.1080/23322039.2020. 1733279.

Muth, J.F. (1961), "Rational expectations and the theory of price movements", Econometrica, Vol. 29 No. 3, pp. 315-335, doi: 10.2307/1909635.

Nofsinger, J.R. (2017), The Psychology of Investing, 6th ed., Routledge, New York.

Oberlechner, T. and Osler, C.L. (2008), "Overconfidence in currency markets”, SSRN Electronic Journal. doi: 10.2139/ssrn.1108787.

Odean, T. (1998), "Volume, volatility, price, and profit when all traders are above average", The Journal of Finance, Vol. 53 No. 6, pp. 1887-1934, doi: 10.1111/0022-1082.00078.

Oprean, C. (2014), "Effects of behavioural factors on human financial decisions", Procedia Economics and Finance, Vol. 16, May, pp. 458-463, doi: 10.1016/\$2212-5671(14)00825-9.

Oprean, C. and Tanasescu, C. (2014), "Effects of behavioural finance on emerging capital markets", Procedia Economics and Finance, Vol. 15 No. 14, pp. 1710-1716, doi: 10.1016/S2212-5671(14) 00645-5.

Pandey, I.M. (2002), "Seasonality in the Malaysian stock market: 1992-2002", Journal of Financial Management and Analysis, Vol. 15 No. 2, pp. 37-44.

Parveen, S. and Siddiqui, M. (2018), "Anchoring heuristic, disposition effect and overconfidence bias in investors: a Case of Pakistan stock exchange”, Abasyn Journal of Social Sciences, Vol. 11 No. 2, pp. 280-294.

Puri, M. and Robinson, D.T. (2007), "Optimism and economic choice", Journal of Financial Economics, Vol. 86 No. 1, pp. 71-99, doi: 10.1016/j.jfineco.2006.09.003.

Rasheed, M.H., Rafique, A., Zahid, T. and Akhtar, M.W. (2018), "Factors influencing investor's decision making in Pakistan”, Review of Behavioral Finance, Vol. 10 No. 1, pp. 70-87, doi: 10. 1108/RBF-05-2016-0028.

Rashid, K. and Islam, S.M.N. (2013), "Corporate governance, complementarities and the value of a firm in an emerging market: the effect of market imperfections", Corporate Governance: The International Journal of Business in Society, Vol. 13 No. 1, pp. 70-87, doi: 10.1108/ 14720701311302422.

Ricciardi, V. and Simon, H. (2000), "The case for behavioral finance: a new Frontier", The Northeast Business \& Economics Association 27th Annual Conference.

Rocciolo, F., Gheno, A. and Brooks, C. (2019), "Optimism, volatility and decision-making in stock markets”, International Review of Financial Analysis, Vol. 66, p. 101356, doi: 10.1016/j.irfa.2019. 05.007.

Sargent, T.J. (1993), Bounded Rationality in Macroeconomics: The Arne Ryde Memorial Lectures, Oxford University Press, Oxford.

Shah, S.Z.A., Ahmad, M. and Mahmood, F. (2018), "Heuristic biases in investment decision-making and perceived market efficiency", Qualitative Research in Financial Markets, Vol. 10 No. 1, pp. 85-110, doi: 10.1108/QRFM-04-2017-0033.

Shanmugham, R. and Ramya, K. (2012), "Impact of social factors on individual investors' trading behaviour", Procedia Economics and Finance, Vol. 2 No. Af, pp. 237-246, doi: 10.1016/S22125671(12)00084-6.

Sharpe, W.F. (1964), "Capital asset prices: a theory of market equilibrium under conditions of risk", The Journal of Finance, Vol. 19 No. 3, pp. 425-442, doi: 10.2307/2977928.

Shepperd, J.A., Carroll, P., Grace, J. and Terry, M. (2002), "Exploring the causes of comparative optimism", Psychologica Belgica, Vol. 42 Nos 1-2, pp. 65-98. 
Shiller, R.J. (1999), "Human behavior and the efficiency of the financial system", in Taylor, J.B. and Woodford, M. (Eds), Handbook of Macroeconomics, Elsevier, Amsterdam, Vol. 1, Part C, pp. 1305-1340, doi: 10.1016/S1574-0048(99)10033-8.

Shiller, R.J. (2003), "From Efficient markets theory to behavioral finance", Journal of Economic Perspectives, Vol. 17 No. 1, pp. 83-104, doi: 10.1257/089533003321164967.

Sias, R.W. and Starks, L.T. (1995), "The day-of-the-week anomaly: the role of institutional investors", Financial Analysts Journal, Vol. 51 No. 3, pp. 58-67, available at: http://www.jstor.org/stable/ 4479847.

Statman, M., Thorley, S. and Vorkink, K. (2006), "Investor overconfidence and trading volume", The Review of Financial Studies, Vol. 19 No. 4, pp. 1531-1565, available at: http://www.jstor.org/ stable/4123481.

Strydom, M., Scally, A. and Watson, J. (2019), "Impact of mood and gender on individual investors' reactions to retractions and corrections of earnings forecasts", Applied Economics, Vol. 51 No. 9, pp. 941-955, doi: 10.1080/00036846.2018.1524125.

Toma, F.-M. (2015), "Behavioral biases of the investment decisions of Romanian investors on the Bucharest stock exchange", Procedia Economics and Finance, Vol. 32 No. 15, pp. 200-207, doi: 10.1016/S2212-5671(15)01383-0.

Trifan, R. (2020), "Behavioural biases and stock market reaction: evidence from six post-communist countries”, Ekonomický Časopis, Vol. 68 No. 8, pp. 811-826, doi: 10.31577/ekoncas.2020.08.03.

Tuyon, J. and Ahmad, Z. (2016), "Behavioural finance perspectives on Malaysian stock market efficiency”, Borsa Istanbul Review, Vol. 16 No. 1, pp. 43-61, doi: 10.1016/j.bir.2016.01.001.

Tversky, A. and Kahneman, D. (1992), "Advances in prospect theory: cumulative representation of uncertainty", Journal of Risk and Uncertainty, Vol. 5 No. 4, pp. 297-323, doi: 10.1007/ BF00122574.

Van den Steen, E. (2004), "Rational overoptimism (and other biases)", The American Economic Review, Vol. 94 No. 4, pp. 1141-1151, available at: http://www.jstor.org/stable/3592809.

Vieira, E.F.S. and Pereira, M.S.V. (2015), "Herding behaviour and sentiment: evidence in a small European market", Revista de Contabilidad, Vol. 18 No. 1, pp. 78-86, doi: 10.1016/j.rcsar.2014. 06.003.

\section{Corresponding author}

Yasir Bin Tariq can be contacted at: yasirtariq@cuiatd.edu.pk

\section{Behavioural errors and investment decisions}

